\title{
Analysis of the Banking Sector in the Czech Republic
}

\author{
Martina Hedvicakova, Pavel Prazak \\ University of Hradec Králové, Faculty of Informatics and Management, Rokitanskeho 62, \\ 500 03, Hradec Kralove, Czech Republic \\ martina.hedvicakova@uhk.cz, pavel.prazak@uhk.cz
}

\begin{abstract}
Forty-six banks and foreign bank branches were operating in the Czech Republic in May 2018. The banking market in the Czech Republic is characterized by high fees for account management and information asymmetries. For this reason, there are number of fees accounts comparators on the market. One of these is the Bank Charge Calculator, which allows clients to run their current account expenditures by their set criteria. The aim of the article is to analyze the current state of the banking sector for individuals. Based on data from the Bank Charge Calculator, a Client Index is calculated to allow respondents to calculate the average monthly cost of running their current account according to defined criteria and service requirements. The value of this Client Index was used to propose a pay-off function in the game theory model. Client Index values serve to express the price level on the RCBS market.
\end{abstract}

Keywords: Game theory, Client Index, bargaining, pay-off matrix, decision tree, bank charges.

\section{Introduction}

There is a high level of competition on the Czech banking market. Nevertheless, Retail core banking services (RCBS) are characterized by a high degree of asymmetry of information. Information asymmetry is a situation where one side of the market benefits from the information advantage at the expense of the second one. This situation does not necessarily mean the market disequilibrium. We can imply the F. A. Hayek's [1] thoughts and say that equilibrium can be achieved under the different levels of informedness. [2] The second problem is high fees for current account in the Czech Republic.

Stigler [3] is solving the situation where the consumer prefers the lowest price on homogenous product, but the prices are yet to be discovered in order to make choice. Soukal and Draesller [2] suggest calculating the optimal price to be searched for. By term optimal price it is meant price that is optimal by search costs to search revenue, in other words total savings, and by the quality and quantity demanded (regarding RCBS we mean range and frequency of the requested services). The optimal price on the market will probably be different from the optimal price computed by the model because of the optimal cost of the search and the probabilistic problem of search. For a closer theoretical description of the rework of Stigler's model please see (Hedvicakova, Soukal, \& Draessler, 2012, [4]). 
Trust is a crucial element of a viable banking industry. Dahlstrom et al. [5] present a structural equations model based on a prisoner's dilemma logic to analyze the unique effects of trust between corporate customers and their banks. The results based on 252 corporate bank customers reveal an intriguing mixed strategy between trust from one party and opportunism from the other. The implication is that mutual trust seems to reduce the perception of risk in the market while bank opportunism significantly escalates perceived risk. They analyses also show that when the corporate customer trusts the bank, perceived risk is significantly reduced.

\section{Theoretical bases}

Customer satisfaction is an important factor in the performance and competitiveness of banks $[6,7,8,9]$. Compliance with the consumers' needs and requirements [10], comprehensive customer care and the bank customers' satisfaction is currently at the centre of attention of researchers and bankers (as it represents an important marketing variable for most of the companies $[11,12,13]$

Mosk [14] examines bargaining as a mechanism to resolve information problems. He develops a parsimonious model of a credit negotiation between a bank and firms with varying levels of impatience. In equilibrium, impatient firms accept the bank's offer immediately, while patient firms wait and negotiate price adjustments. Mosk [14] examines bargaining as a mechanism to resolve information problems.

The issue of increasing profit and reducing operational costs is the most important subject in banking management. One of the ways to solve this problem, is the cooperation (coalition) of banks together in order to reduce costs and simultaneously increase the operating profit. To solve this problem is Khanizad and Montazer [15] model for the participation of banks using game theory with which the banks can cooperate to achieve higher profits while providing their services.

On the other hand, given the current competitive environment among banks in the capital market, less attention has been paid to the cooperation of banks in providing services and attracting customers and investments and consequently studies of banks co-operation in providing services in the micro market (retail customers) were often on the limited inter-banking cooperation. For example, in some studies such as references. [16, 17. 18, 19], [15].

We live in what might be called the imperial age of game theory, in whichgame heory has become influential in an ever-growing variety of other disciplines.Game theory is now a standard tool in political science but can be used in all sectors, including banking. For example, McCarty and Meirowitz (2007) provide a book-length overview of how game theory can be used to examine the relations between countries, the behavior of political parties, electoral behavior, the workings of legislatures, lobbying, and so on. [20]

Game theory usually analyses decision-making processes in various fields. Kapliński [21]. Our research is oriented in the fields of game theory with application in banking sector. 
According to most authors, the criterion for dividing bargaining is whether the bargaining defends the position or interests of clients. There is a contrast in the terminology between the individual types of bargaining. For example, Plamínek [22] distinguishes between competitive, cooperative, virtual and principled bargaining. As early as six years later, the same author [23] only sets forth competitive, cooperative and principled bargaining. Holá [24] sets forth positional (competitive) bargaining and constructive (principled) bargaining [25]. [13]

\section{The aim and methodology of the paper}

In the Czech Republic there is a high asymmetry of information on the RCBS (Retail core banking services) market. For this reason, clients are searching on the internet for a variety of comparison, according to which they would find the cheapest bank account according to their preferences and the services they use. For this reason, a Bank Charges Calculator was created, available at: http://www.bankovnipoplatky.com/kalkulator.html, which compares the average monthly cost of running a current account according to the criteria specified by the respondent. The frequency of the individual items of the fee schedules is monitored based on a questionnaire (e.g. how many times clients use the given service and how much is charged for the service, what turnover and balance they have in their accounts, etc.) The Client Index was calculated based on these data. Since 2013, the Client Index is calculated quarterly using the statistical software IBM PASW 18 and MS Excel 2013. Data on the amount of bank charges and commissions has been obtained from publicly available data by banks (fee schedules, annual reports, bank accounts and documents on the financial situation of the bank, etc.). The average costs of a specific account are established by the arithmetic average of clients who have chosen the monitored account computed by the Calculator. See equations 1 and 2. Data collection took place from 2012 until first quarter 2018. The calculation is preceded by the verification validation part, in order not to distort the result e.g. respondents who should not use retail products (self-employed, small entrepreneurs with frequencies of banking services which the client can never achieve in the civil account) or respondents who only form clicked without key services. This methodology is more accurate, but it requires a greater number of clients. The number of accounts with a lack of respondents for calculation is much higher. On average, 2000 respondents filled in the Calculator per quarter. For a more detailed description of the methodology see e.g. [26, 27, 28] or [13]. The author of the article analyzes the data for this project.

$A C_{h}=\frac{1}{n_{h}} \sum_{h=1}^{k} \sum_{i=1}^{n_{h}} c_{h i}$,

where $A C_{\mathrm{h}}$ represents average costs of account number $h$, further $i$ represents client serial number, $c_{\mathrm{hi}}$ is the cost of client $i$ that uses account $h$ monthly, $k$ is the total number of monitored accounts and $n_{\mathrm{h}}$ is the number of clients that use accounts $h$. More details can be found in [27,28]. For the rest of calculation can be used the following formulas 


$$
\begin{aligned}
& w_{h}=\frac{n_{h}}{n} \\
& C I=\sum_{h=1}^{k} w_{h} \cdot A C_{h}
\end{aligned}
$$

It means that the resulting value of the Client Index (2) is calculated as the weighted value of the average cost of each account. Scales are derived from relative frequencies, respectively: of the shares of respondents of individual accounts as a whole. [27, 28].

The aim of the article is to analyze the current state of the RCBS market in the Czech Republic. Based on the Client Index calculations for each quarter, calculate the average value that clients pay on average for managing their current account monthly and quarterly. This amount includes, for example, fees for credit and debit cards or insurance, which is paid once a year. The calculated average value Client Index will be used in game theory chapter for negotiation between the client and the bank. Client Index values serve to express the price level on the RCBS market.

\section{Actual situation in the banking sector in the Czech Republic}

In May 2018, 46 banks and foreign bank branches were operating in the Czech Republic (excluding the CNB). The number of banks is increasing, even though it currently holds a bank license for one bank less than in 2017. In 2009, 39 banks were in the market and 47 banks in 2017. The largest share of this increase was made by branches of foreign banks from the European Union, from 18 in 2009 to 23 in 2017.

Although the number of licenses granted by the bank grows, there is a gradual reduction in the number of branches. This trend is mainly due to the growing influence of digitization, which takes place worldwide, and of course in the Czech Republic. The reduction of branches in small towns takes place mainly at the three largest banks in the Czech Republic: Česká spořitelna, Komerční banka and ČSOB. These banks have the widest network of branches from all banks in the banking market in the Czech Republic. There is also a reduction of branches and staff reductions.

With the growth of digitization, there is increasing number individuals using Internet Banking. In 2017, 52\% of individuals used Internet Banking in the Czech Republic. Internet banking is the most used age group of 25-44 years. See Figure 1.

Using Internet Banking instead of bank branches brings savings to clients. Clients can pay lower costs for account management.

The Czech Republic is in the percentage of individuals using Internet banking above the European Union average. Around half (51\%) of adult Europeans use internet banking. This share is constantly increasing and has doubled since 2007, when it stood at $25 \%$. Internet banking is particularly popular among 25 to 34 years old, with $68 \%$ using this facility. The use of internet banking tends to increase in line with the education level of the user [30]. 


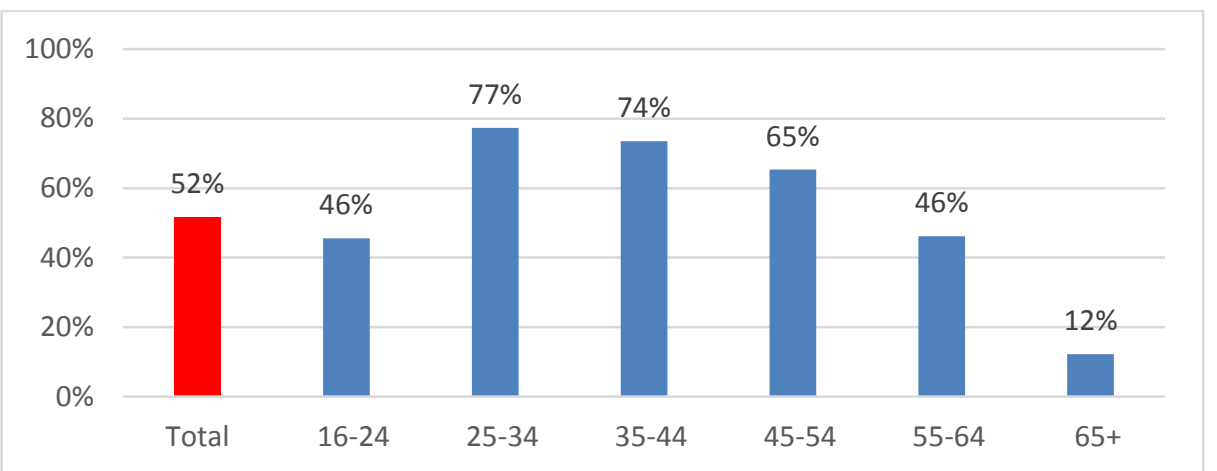

Fig. 1. Individuals using Internet Banking by age in 2017, Source: Czech Statistical Office, [29], own processing

The total assets of the Czech banking sector stood at CZK 7,564 billion at the end of May 2018. Loans to residents are the predominant asset item. Their volume reached CZK 5,609 billion. Deposits of residents, which are the most important item among banking sector liabilities, totaled CZK 4,397 billion. [31].

Among the three largest banks, according to the number of clients operating on the Czech banking market, are Česká spořitelna, ČSOB and Komerční banka. The fourth bank, which has over millions of clients, is Moneta. See table 1.

Most clients lost the largest bank: Česká Spořitelna. Still more clients get "low-cost" banks such as mBank, Air Bank or Fio Bank. More and more citizens of the Czech Republic have more than one bank account. This causes a high level of competition in the banking market. Bank clients also have chance for bargaining with the main bank. They can negotiate free of charge or premium services.

The second criterion for bank size is the size of the total assets. The Czech National Bank ranks among the big banks with financial institutions with a total asset of over CZK 400 billion. The largest three banks are ČSOB, which exceeded CZK 1.5 trillion, the second is Česká spořitelna and the third Komerční banka. The last bank that meets the criteria of the Czech National Bank is a bank Unicredit Bank. [32].

1 Euro is 25,92 CZK in July 2018.

Table 1. Number of clients in 2015 and 2018, [32, own processing], *2017

\begin{tabular}{lll}
\hline Bank & to 31.3 .2018 & to 31.3 .2015 \\
\hline Česká spořitelna & 4,68 million & 5 million \\
ČSOB & 3,671 million & 2,9 million \\
Komerční banka & 1,666 million & 1,6 million \\
Moneta/GE Money Bank & 1,034 million & 1 million \\
Fio banka & 815 million & 480000 \\
mBank & $650000^{*}$ & 534000
\end{tabular}




$\begin{array}{lll}\text { Raiffeisenbank } & \text { not published } & \begin{array}{l}\text { not published } \\ \text { estimated } 500000 \\ 343000\end{array} \\ \text { Air Bank } & 618342 & 343000 \\ \text { UniCredit Bank } & 415000 & \text { did not exist } \\ \text { Hello bank } & 400000 * & 140000 \\ \text { Equa bank } & 323000 & 86000 \\ \text { Sberbank } & 115000 & \text { not published } \\ \text { Creditas } & 40000 & \text { not published } \\ \text { Expobank } & 20261 & \text { not published } \\ \text { Oberbank } & 16000 & \end{array}$

The population of the Czech Republic was 10613350 at 31 March 2018 according to the Czech Statistical Office. Table 1 shows that most people have more than one current account in the Czech Republic. Clients are trying to reduce account costs by combining current accounts with different banks.

\section{The results of the research of bank charges}

In 2014, the Client Index level was in the range of 179 - 183 CZK per month $(6,905$ 7,06 Eur / month). 1 Euro is CZK 25.92 in July 2018. Due to the low difference in index values, the Client index is expressed in CZK only.

The following year, the biggest fluctuations took place. The Client Index ranged from 180 to $188 \mathrm{CZK}$ / month. See figure 2.

Since 2016, the average cost of the bank account has stabilized at $184-186 \mathrm{CZK} /$ month. And this trend continued in the years to come. The highest value of the Client Index was in the fourth quarter of 2017, when clients paid an average of $189 \mathrm{CZK}$ for maintaining their account. In the next quarter there was only a slight decrease of one crown. The increase in the value of the Client Index in the last quarters of the given years is due to the increased shopping activity of clients during Christmas and the increased use of debit and credit cards associated with the selection from foreign ATMs. Also, during summer holidays, bank account fees are increasing due to withdrawals from ATMs abroad, which are charged at higher rates in most banks.

Analysis of the survey data revealed that the average Client Index is $185 \mathrm{CZK}$ between 2014 and the first quarter of 2018. This value was used in the game theory chapter and value modeling is built on this value. This value was calculated as the arithmetic mean of all valid values from the questionnaire survey in 2014-2018. It is important for setting the average amount for running a current account monthly and for negotiation. 


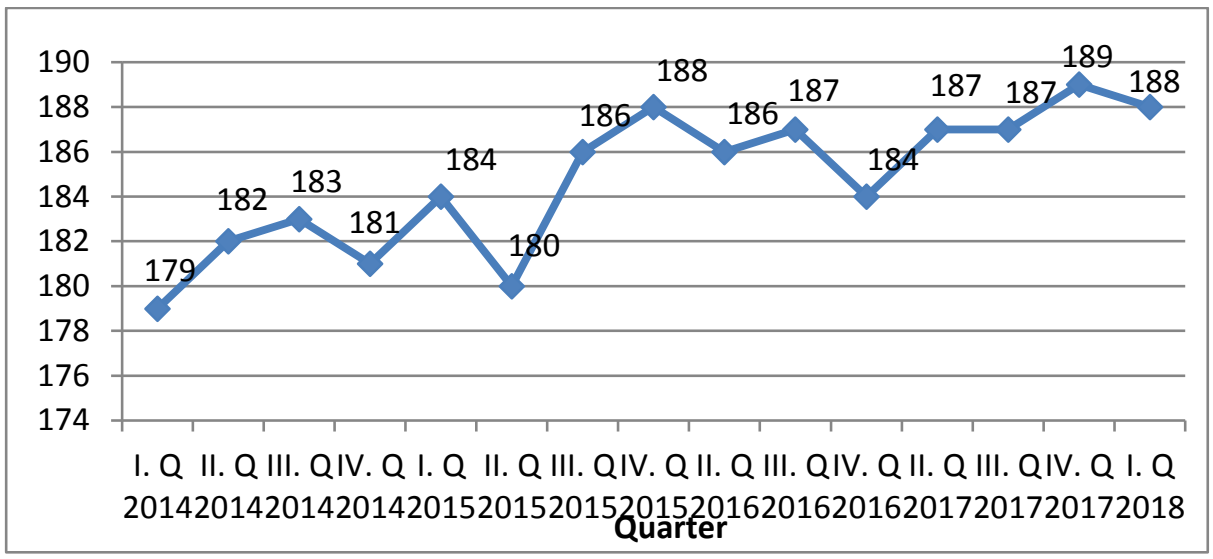

Fig. 2. Client Index - the average costs of bank account in CZK, Source: www.bankovnipoplatky.com, The author's own arrangement,

It is very interesting that even though several low-budget banks have entered the market in the last seven years and many clients have set up an account with them. the value of the Client Index did not change significantly and recorded a sharp rise in the penultimate quarter of 2015.This is most likely due to the fact that clients still keep their current account even with a large bank that has not canceled and pays the fees. And lowcost banks have higher charges for their premium services.

\section{Game theory during the bargaining process between the bank and the client}

The relationship between the bank and its client regarding bank charges can be considered as a conflict of two players in game theory. Game theory deals with mathematical modelling of problems in which it is necessary to choose decision-making processes [13], [33], [34], [35].

In the game related to bank charges, which shall be labelled $\mathrm{G}$, we will consider two players, the bank B and its client K, [13]. If the set of players is labelled by $\mathrm{H}$, then $\mathrm{H}=\{\mathrm{B}, \mathrm{K}\}$. The client $\mathrm{K}$ shall have two strategies available; he/she can be active or passive. In case of the active strategy A, he/she shall be interested in the amount of charges for the maintaining of his/her account with the bank, he/she shall demand a discount and in case the bank does not grant it, he/she will be ready to leave for another bank. In case of the passive strategy $\mathrm{P}$, he/she shall not be actively interested in discounts for maintaining his/her bank account, however, he/she will not refuse them if they are offered and he/she will not be ready to change banks. Therefore, for the set of strategies $X_{K}$ of the client, $X_{K}=\{A, P\}$. The bank B shall also have two strategies available; it can either offer cooperation or it remains firm. In case of the cooperative strategy that is denoted $\mathrm{S}$, it shall offer its client a discount for maintaining the client's account or benefits. In case of firm strategy N, the bank shall not offer either any discount for maintaining the account or any benefits. Therefore, for the set of strategies of 
the bank $X_{B}, X_{B}=\{S, N\}$. Let's label the pay-off functions of the client $C$ or bank $B$ respectively, $f_{K}(x, y)$ or $f_{B}(x, y)$ respectively, where $x \in X_{K}$ a $y \in X_{B}$. These pay-off functions shall express the price for maintaining an account in CZK. The values of the pay-off function of the bank $\mathrm{f}_{\mathrm{B}}(\mathrm{x}, \mathrm{y})$ can be summarized using the following table 2 . If we consider an antagonistic conflict, where one of the players wins what the other player loses, it holds that $f_{K}(x, y)+f_{B}(x, y)=0$ and it is a zero-sum game. The values of the pay-off function of the client $f_{K}(x, y)$ have the opposite sign, so it is not necessary to state them explicitly. The interpretation of these pay-offs may be, for example, as follows: $\mathrm{f}_{\mathrm{B}}(\mathrm{A}, \mathrm{N})=-188$ means that if the bank does not accede to the proposal of the active client, it loses an income of $188 \mathrm{CZK}$ per month (this is the value of the Client index calculated in the previous chapter). Similarly, $\mathrm{f}_{\mathrm{B}}(\mathrm{P}, \mathrm{N})=188$ means, that if the bank does not offer any discount to the passive client, it keeps a monthly income of 188 CZK.

Table 2. Values of the pay-off matrix of the bank, Source: The author's own arrangement

\begin{tabular}{|l|r|r|}
\cline { 2 - 3 } \multicolumn{1}{c|}{ client K/bank B } & S & N \\
\hline $\mathbf{A}$ & 50 & -188 \\
\hline $\mathbf{P}$ & 120 & 188 \\
\hline
\end{tabular}

The optimum strategy of the players can be found using the Nash equilibrium [33]. This is a game configuration that has the following property for each of the players: if all the other players use strategies from the given equilibrium, then the individual player cannot increase his or her pay-off by choosing a different strategy.
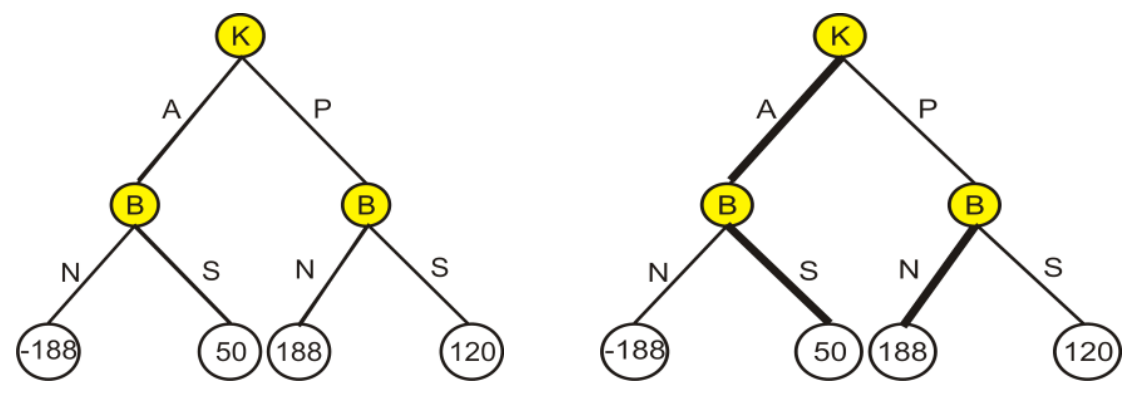

Fig. 3. On the left is the game tree with decision nodes $K$ and $B$ in which the client $K$, or the bank B make decisions and with final nodes that express the value of the game from the bank's point of view. On the right is the same game tree that demonstrates backward induction. Source: The author's own arrangement.

We shall further assume that it is a game with complete information where the players know the sets of their strategies and the amounts of their pay-offs. We shall characterize the game using a sequence of decisions by the client and the bank that follow 
one after another. We shall therefore suppose it is a game in an extensive form that can be illustrated using the game tree at Fig. 3 .

The game in the extensive form can be solved using the method of backward induction, [34]. This method is also depicted at Fig. 3. Let's consider all the decision nodes whose edges lead to the final nodes of the game tree. In the present case, these are two nodes of player B. In each of these decision nodes, we choose the edge that leads to the best final node from the perspective of the player to whom the node belongs, and we highlight it. We note the determined edge. For each decision node, we assign the payoffs that correspond to the found best final node. We leave out all the edges stemming from the decision node, including their final nodes. This way there arises a new decision tree with new final points and their pay-offs. The whole procedure can now be repeated until we get to the root of the game tree. In our case, we finish after two steps and the rational client $\mathrm{K}$ chooses the edge that leads to a lower monthly charge for maintaining the account, i.e., he/she chooses the strategy of an active client A, see Fig. 3. This is how we found the Nash equilibrium $\left(\mathrm{x}^{\mathrm{o}}, \mathrm{y}^{\mathrm{o}}\right)=(\mathrm{A}, \mathrm{S})$, which means that the bank client should be active during the bargaining process about the monthly price for his or her bank account. The bank should offer its client a discount so as not to lose him or her. It needs to be stressed that this result was obtained under the assumption that the game participants have complete information available, when the players know all the possible scenarios of the game. The requirement of an informed and active bank client is essential to achieve the found result of the game. The result leads us to the type of bargaining known as WIN-WIN.

\section{Conclusion and discussion}

The aim of the article was to analyze the current situation on the banking market in the Czech Republic. Using the Client Index, which measures the average cost for a current account per month were calculated quarterly average values (up to 2015 were calculated as monthly and quarterly value). The average client will pay CZK 188 per month $(7,137$ Eur / month) at the bank. This value was used in the last section dealing with banking theory.

The Czech banking market is changing and digitizing. Czech Republic in the number of users of Internet banking on the average of the European Union. Due to the high number of banks, there is a high level of competition in the banking market. Banks are forced by clients to constantly develop new technical innovations. One of them is the simplest and most intuitive control of Internet banking. At present, however, emphasis is placed on mobile banking. Banks are trying to attract clients with new solutions and security measures that are quick and easy to control. This is one of the reasons why clients stay with large traditional banks where they pay high fees for managing their account, even though the market is constantly growing with low-cost banks that offer free account maintenance's.

According to the Czech Statistical Office, the Czech Republic has 10613350 inhabitants. Table 1. Number of clients in 2015 and 2018 shows that the Czechs own more 
than one bank account. Czechs are a conservative nation and, despite the high cost of keeping an account, they do not interrupt their account with a large bank.

Solutions and opportunities for banks and clients is a novelty on the market - open banking.

The European directive known by the acronym PSD2 (Payment Services Directive 2) gave an open banking, aimed at creating a single market for payments through the regulation of banks and new payment service providers. The new Czech Payment System Act, which entered into force in January 2018, is also based on this directive.

As a result, clients are gradually being able to manage their payment accounts with different banks and carry out certain operations with them through just one mobile or Internet application. Open banking enabled Creditas first, followed Fio, Equa bank or Air Bank. By the end of the year wants to establish an open banking, other banks such Česká spořitelna and others, [37].

Through open banking, clients can better manage their money and better manage and monitor the amount of individual product and service charges. This can reduce the monthly cost of managing your bank accounts. This also gives them a better chance of negotiating with the bank.

In terms of bargaining and game theory, WIN-WIN has emerged as the best strategy. The WIN-WIN strategy is most often applied in practice because banks try not to lose their clients. If the client actively negotiates, they will in most cases comply with it. It is a question for discussion why the citizens of the Czech Republic do not negotiate more with the bank and prefer to create new accounts, even if they keep their old account.

\section{Acknowledgement}

The paper was written with the support of the specific project 6/2018 grant "DETERMINANTS OF COGNITIVE PROCESSES IMPACTING THE WORK PERFORMANCE" granted by the University of Hradec Králové, Czech Republic. We would like to thank student Eliška Čnková for cooperation in the processing of the article.

\section{References}

1. Hayek, F. A. (1958). Individualism and economic order. Chicago: University of Chicago press.

2. Soukal I., Draessler, J. (2012). Consumer desired price modeling - case study on the RCBS market. Procedia - social and behavioral sciences. 62, p. 916-920. ISSN 1877-0428.

3. Stigler, G. J. (1961). The economics of information. The journal of political economy, pp. 213-225.

4. Hedvicakova, M., Soukal, I., \& Draessler, J. (2012). Probabilistic Model of Optimal Price Search on the Retail Core Banking Services Market. International Journal of Mathematical Models and Methods in Applied Sciences, pp. 386-393.

5. Dahlstrom, R., Nygaard, A., Kimasheva, M., lvnes, A.M. (2014). How to Recover Trust in the Banking Industry? A Game Theory Approach to Empirical Analyses of Bank and Corporate Customer Relationships. International Journal of Bank Marketing 32(4):268-278, DOI: 10.1108/IJBM-03-2014-0042 
6. Keisidou, E., Lazaros, S., Maditions, D.I., \& Thalassinos, E.I. (2013). Customer satisfaction, loyalty and fi nancial performance: a holistic approach of the Greek banking sector. International Journal of Bank Marketing, 31(4), 259-288. doi:10.1108/IJBM-11-2012-0114

7. Chavan, J., \& Ahmad, F. (2013). Factors Affecting On Customer Satisfaction in Retail Banking: An Empirical Study. International Journal of Business and Management Invention, 2(1), 55-62

8. Hedvicakova, M. (2017). Key study of bank accounts for young people with using multicriteria optimization and fuzzy analysis, Applied Economics, Vol. 49, 2017 (36).PP. 35993610. DOI: 10.1080/00036846.2016.1265073

9. Belás, J., Chocholáková, A., \& Gabčová., L. (2015). Satisfaction and loyalty of banking customers: a gender approach. Economics and Sociology, 8(1), 176-188. doi:10.14254/2071- 789X.2015/8-1/14.

10. Bilan, Y. (2013). Sustainable development of a company: Building of new level relationship with the consumers of XXI. Century. Amfi teatru Economic, 15(7), 687-701.

11. Munari, L., Lelasi, F., Bajetta, L. (2013). Customer Satisfaction Management in Italian Banks. Qualitative Research in Financial Markets, 5(2), 139-160. doi:10.1108/QRFM-112011-0028.

12. Belás, j., Lenka Gabčová, L. (2016). The relationship among customer satisfaction, loyalty and financial performance of commercial banks. 19(1), p.132 - 147, E\&M Ekonomie a Management, DOI: dx.doi.org/10.15240/tul/001/2016-1-010

13. Hedvicakova, M., Prazak, P. (2018). Bargaining between the client and the bank and game theory, European, Mediterranean and Middle Eastern Conference on Information Systems (EMCIS), Limasol, Cyprus, in press

14. Mosk, T. C., (2018). Bargaining with a Bank. SAFE Working Paper No. 211. Available at SSRN: https://ssrn.com/abstract=3186111 or http://dx.doi.org/10.2139/ssrn.3186111

15. Khanizad, R., Montazer, G. Participation against competition in banking markets based on cooperative game theory, The Journal of Finance and Data Science, Volume 4, Issue 1, March 2018, Pages 16-28, https://doi.org/10.1016/j.jfds.2017.09.002

16. Faigle, U., Kern, W. (1992). The Shapley value for cooperative games under Precedence Constrains, Int J Game Theory, 21 (1992), p. 249-266

17. Katsev, I., Yanovskaya, E. (2013). The prenucleolus for games with restricted cooperationMath Soc Sci, 66 (2013), pp. 56-65

18. Naumova, N. (2012). Generalized proportional solutions to games with restricted cooperation, L.A. Petrosyan, N. Zenkevich (Eds.), Contributions to Game Theory and Management, vol. 5, Graguate School of Management SPbU, Saint Petersburg (2012), pp. 230-242

19. Bjorndal, E., Hamers, H. Koster, M. (2014). Cost allocation in a bank ATM network Math Methods Oper Res, 59 (2004), pp. 405-418

20. Samuelson, L. (2016). Game Theory in Economics and Beyond. Journal of Economic Perspectives-Volume 30, Number 4-Fall 2016-Pages 107-130

21. Kapliński, O., Tamošaitiene, J. (2010). Game theory applications in construction engineering and management. Journal Ukio Technologinis ir Ekonominis Vystymas, Volume 16, 2010 - Issue 2, Pages 348-363

22. Plamínek, J. (1994). Řešení konfliktů a umění rozhodovat. Vyd. 1. Praha : Argo, 198 s. ISBN: 8085794144.

23. Plamínek, J. (2000). Synergický management: vedení, spolupráce a konflikty lidí ve firmách a týmech. Praha: Argo, 328 s. ISBN 80-7203-258-5

24. Holá, L. (2011). Mediace v teorii a praxi, Praha, Grada Publishing, 272 s., ISBN: 978-80247-3134-6. 
25. Fisher, R., URY, W., Patton, B (1994). Dohoda jistá: zásady úspěšného vyjednávání. Vyd. 1. Přeložil Aleš Lisa. Praha: Management Press, 174 s.. ISBN 80-85603-48-9.

26. Bankovní poplatky, (2018). Klientský index - metodika. Retrieved May 15, 2018, from: https://www.bankovnipoplatky.com/klientsky-index---metodika-12507.html

27. Draessler, J., Soukal, I., Hedvičáková, M. (2011). Shluková analýza poptávkové strany trhu základních bankovních služeb. E+M Ekonomie a Management, 14(4), 102-114. ISSN: 12123609 .

28. Soukal, I., \& Hedvicakova, M. (2010). Retail core banking services e-banking client cluster identification. Procedia Computer Science Journal , pp. 1205-1210.

29. Czech Statistical Office, (2018). Informační společnost v číslech - 2018, Retrieved June 10, 2018, from: https://www.czso.cz/csu/czso/informacni-spolecnost-v-cislech

30. Eurostat, (2018). Internet banking on the rise, Retrieved June 10, 2018, from: http://ec.europa.eu/eurostat/web/products-eurostat-news/-/DDN-20180115-1

31. Czech National Bank. (2018)., Retrieved June 10, 2018, from: https://www.cnb.cz/en/statistics/money_and_banking_stat/banking_statistics/bank_stat_komentar.html

32. Aktualne.cz. (2018). Retrieved June 10, 2018, from: https://zpravy.aktualne.cz/finance/nejvetsi-banky-v-cesku-zebricek-bank-podle-velikosti-poradi/r $\sim$ ba7b166e5a6a11e8bacfac1f6b220ee8/?redirected $=1532079954$

33. Carmichel, F. (2005). A Guide to Game Theory. Prentice Hall. Harlow. ISBN 0-273-684965.

34. Gintis, H. (2009). Game Theory Evolving, A Problem-Centered Introduction to Modeling Strategic Interaction. Princeton University Press, New Jersey. ISBN 978-0-691-14050-6.

35. Vega-Redondo, F. (2003). Economics and the theory of games. Cambridge University Press. Cambridge. 2003. 978-0-521-77590-8.

36. Brualdi, R.A. (2010). Introductory Combinatorics, Prentice Hall. New Jersey. ISBN 0-13602040-2

37. Novinky.cz. (2018). Retrieved June 20, 2018, from: https://www.novinky.cz/finance/477529-otevrene-bankovnictvi-se-rozjizdi.html 